\title{
An Evaluation of Spatial Information Processing in Aged Rats
}

\author{
Peter R. Rapp, Ruth A. Rosenberg, and Michela Gallagher \\ University of North Carolina at Chapel Hill
}

\begin{abstract}
The spatıal learning abılıtıes of young, middle-age, and senescent rats were investigated in two expenments using several versions of the Morris water maze task In Expenment 1, Long-Evans hooded rats were trained to find a submerged escape platform hidden within the water maze Durnng this phase of testıng, aged rats exhibited acquisition deficits compared with either young or middle-age subjects With contınued trainıng, however, all age groups eventually achieved comparable asymptotıc levels of performance Subsequent testıng in Expenment 1 revealed that following original training, aged rats were not impaired in learning a novel escape location or in their ability to locate a visible, cued escape platform In an attempt to identify the basis of the age-related impairments observed in Expenment 1, naive young and aged rats in Experiment 2 were initially tested for their ability to locate a cued escape platform in the water maze During this phase of testıng, the escape latencies of both young and aged rats rapidly decreased to equivalent asymptotic levels Subsequent analyses revealed that following cue training, young subjects exhibit a significant spatial bias for the region of the testing apparatus where the platform was positioned durng training In contrast, aged rats showed no spatial bias Training was contınued in Experıment 2 using a novel submerged platform location for each subject Dunng these place training trials, the escape latencies of senescent rats were longer than those of young subjects These impairments were also accompanied by a lack of spatial bias among aged rats relative to young control subjects In combination, the results of these investigations indicate that age-related imparments in water maze performance reflect a specific deficit in the ability of aged rats to utılize spatial information
\end{abstract}

In recent years the number of investigations focusing on the identıfication of age-related changes in learning and memory has nsen dramatucally. Related to this intensified research effort is an increasing growth in the proportion of aged individuals in the population Because the incidence of varIous forms of cognitive deterioration is well documented to increase with increasing age (Botwinick, 1978), an important focus of current research is to delineate age-related changes in learnıng and memory in laboratory anımals Such investigatıons may, therefore, highlight specific cognitıve processes that are compromised in senescence, as well as provide insight into possible neural sites and mechanisms of senescent memory decline.

In this context, a number of investigations utılizing a wide range of behavioral testing procedures have demonstrated that the performance of aged animals is impaired relative to young subjects (see Kubanis \& Zornetzer, 1981, for a recent review) Perhaps the most consistent finding across investigations using rodents is that aged rats are impaired in tasks that young animals solve using spatial information Specifically, spatial information processing in aged rats has been studied using a number of testıng procedures including the Barnes hole-board task (Barnes, 1979, Barnes, Nadel, \& Honıg, 1980), the 8-arm

This research was supported by National Institute of Mental Health Grant MH 39180, a Research Scientist Development Award (Natuonal Institute of Mental Health) K02 MH00406 to Michela Gallagher, and a Grant-ın-Aıd Research from Sigma Xı to Peter R Rapp

Correspondence concerning this article should be addressed to Peter R Rapp, who is now at The Salk Institute for Biological Sciences, Developmental Neurobiology Laboratory, P O Box 85800 , San Diego, Calıfornia 92138 radial maze (Barnes et al., 1980; Davis, Idowu, \& Gibson, 1983, de Toledo-Morrell, Morrell, \& Fleming, 1984; de Toledo-Morrell, Morell, Fleming, \& Cohen, 1984, Gallagher, Bostock, \& Kıng, 1985, Wallace, Krauter, \& Campbell, 1980), the 12-arm radial maze (Ingram, London, \& Goodrick, 1981), as well as the Morris water maze (Gage, Dunnett, \& Bjorklund, 1984). Despite differences in testing procedures and anımal strains across these studies, old anımals have exhıbited acquisition deficits in each case These findings therefore suggest that spatial memory testıng procedures may be particularly sensitive to changes in learning and memory in aged rats. In attempts to assess age-dependent changes in cognitive function, however, it has proven difficult to dissociate the involvement of learnıng and memory processes, per se, from the contribution of nonspecific factors to learned performance. That is, because aging is accompanied by a broad range of sensory, motoric, and motıvational changes in addition to impaired cognitive function, it is important to assess the relative contributions of these vanous factors to observed behavioral deficits in aged animals To date, however, relatively few studies have provided such an analysis

Recently, a behavioral testıng procedure has been developed that permits a direct measurement of many nonspecific factors that contribute to learned performance In this task, known as the Morris water maze, young rats learn the location of a submerged escape platform hidden in a tank of clouded water (Morris, 1981) The nature of the information learned durng training can then be assessed by imposing infrequent probe trials in which the escape platform is removed from the maze and the subject is permitted to swim for some fixed period of time During these "free swim" trials, well-trained rats consistently spend the greatest amount of time swimming 
In the quadrant of the maze that formerly contaned the escape platform. In addition, trained rats cross the former location of the platform more often than other areas of equal size located in the centers of the remaining three quadrants of the apparatus (1.e, the platform locations used for other subjects) Because no visual or olfactory cues are avalable within the maze, it appears that the spatial bias exhibited by animals trained in the Morns water maze is supported by the presence of extramaze cues in the testıng environment This interpretation is also consistent with the demonstration that manipulations which disrupt performance in other spatial tasks ( $1 \mathrm{e}$, lesions of the hippocampus or its major connectrons, O'Keefe \& Nadel, 1978) also imparr acquisition in the water maze (Morns, Garrud, Rawlıns, \& O'Keefe, 1982; Morris, Garrud, \& Woodhouse, 1980, Schenk \& Morns, 1985; Sutherland \& Dyck, 1983) In addition, because both quadrant times and annulus crossings are not latency measurements, they provide information concerning spatial learning that is largely unconfounded by the motonc capacity of the subjects tested This consideration is especially important in research investigating cognitive changes in aging because, as has been noted, age-dependent alterations in many nonspecific factors can contribute to performance differences between young and senescent subjects

Importantly, a second vanety of testing in the Morns task measures sensory, motor, and motivational contributions to learned performance On these trals, animals are permitted to escape onto a black platform that protrudes shghtly above water level Dunng this cue training procedure, young rats rapidly learn to escape onto the visible platform even when the platform is moved randomly to vanous locations in the maze (Morns, 1981). In the context of research on aging, cue training in the Morris task permits an analysis of whether aged anımals have sufficient sensory and motoric capabilities to swim to a goal object, and whether they are motivated to escape This information is critical because it drectly measures those capacities of anmals that are required for normal acquisition in the earlier described place version of the task which, in addition, requires the retention and utilization of spatial information

In light of the above considerations, we hypothesized that performance in the Morns task might prove sensitive to agerelated changes in spatial behavior, and that this testing procedure could yield a more detaled analysis of the variables contributing to observed behavioral deficits in aged subjects than has previously been reported (Gage et al, 1984) The following therefore reports the results of investigations destgned to study spatial information processing in young, middle-age, and senescent rats utılızing the Morns water maze

\section{Experiment 1}

\section{Method}

Young ( 6 months $n=11)$, middle-age ( 12 months, $n=11$ ), and aged (23-28 months $n=11$ ) male Long-Evans hooded rats were obtained from Charles River Laboratones The ages indicated above denote the age of subjects at the conclusion of behavioral testing All middle-age and senescent anımals were obtained as retıred breeders at $8-9$ months of age Subjects were singly housed in the Department of Psychology vivarium for at least 1 month pror to testung The animal colony is maintained at an ambient temperature of $24^{\circ} \mathrm{C}$ with a $1212 \mathrm{hr}$ light/dark cycle (lights on at 0700 hour) Anımals were provided with water and standard laboratory rat chow ad lib throughout all experiments

The testing apparatus used in these expermments was constructed from a large animal watering tank (FCX Corporation, Carrboro, NC), which measured $183 \mathrm{~m}$ in diameter and $584 \mathrm{~cm}$ in depth The interior of the tank was flat white Prior to testıng, the maze was filled to a depth of $355 \mathrm{~cm}$ with water mantained at $26{ }^{\circ} \mathrm{C} \pm 1 \mathrm{C}$ The two escape platforms used in the task were constructed from $102 \mathrm{~cm}$ diameter PVC piping covered at one end with wire mesh One platform was white and measured $345 \mathrm{~cm}$ in height, and the other was black and measured $365 \mathrm{~cm}$ in height Thus, when placed in the filled apparatus, the white platform remained submerged $1 \mathrm{~cm}$ below water level, whereas the black platform protruded $1 \mathrm{~cm}$ above the surface of the water Only one platform was placed in the tank dunng any phase of testıng The white and black platforms. respectively, were used in the place and cue versions of the Morns task described below Before testing, water in the maze was opacified by the addition of $09 \mathrm{~kg}$ of dry powdered milk (Land O'Lakes Corp, WI) Following each day of testing, the tank was drained and cleaned

For all tnals, subjects were videotaped through a wide-angle lens attached to a camera mounted directly above the center of the maze In addition to this equipment, the testing environment contained an abundance of extramaze cues, which included several standard laboratory tems (e g . supply cabinets, sink, shelves, etc) as well as the experimenter

Behavoral lesting procedures Pnor to behavioral testing, all subjects were handled dally (approximately $2 \mathrm{~min} /$ day) for 1 week On Day 1 of testıng. anımals were habituated to the apparatus by placing each subject in the maze for $90 \mathrm{~s}$ with no escape platform present Immediately following this habituation tnal, subjects were returned to the home cage Beginning on Day 2, all subjects were tested in the place version of the task for 31 trials, 2 trals per day, 5 days per week For each animal, the submerged platform was fixed in the center of one quadrant of the maze and remained in that location across these training trals The platform location among animals in each group, however, was counterbalanced Subjects were placed in the maze facing away from the center of the apparatus from one of four equally spaced points along the pernmeter of the tank Entry points were randomly varied with the qualıfication that each anımal was placed in the maze at each entry point once across every four trals Dunng tranning, escape latencies were measured as the time after being released in the maze until the subject escaped onto the platform For all trials, after escaping, subjects were allowed to remain on the platform for $60 \mathrm{~s}$ Trial 2 of each day's training began immediately following this 60 -s penod A 120 -s cutoff was imposed on all tnals If an anımal falled to escape durıng this $2-\min$ period, it was placed on the platform by the expermenter for $60 \mathrm{~s}$ Following the second trial of the day, anmals were returned to the home cage

Subjects were trained as described above for 31 trals Immediately following Trial 31 , the escape platform was removed from the apparatus and the subject was placed in the maze for a 90-s interval From video tapes filmed dunng this free swim, it was possible to denve two measures of spatial behavior in the task One measure. quadrant time. is the number of seconds animals spent in each of the four quadrants of the maze Another measure, anmulus crossings, refers to the number of tımes subjects traversed the actual locatıon of the escape platform used during testıng compared with the number of crossings made over the three remaining platform locattons used for other anımals These measures are important because they directly reflect the degree to which behavior in the task is based on extramaze spatial information 
Trainıng was subsequently contınued for Trials $33-40$ by returnıng the submerged platform to its former location for each animal and testing subjects exactly as before for two trals per day Beginning on Tnai 4I, animals were tested in a transfer training procedure in which the escape platform was moved to the center of the quadrant opposite to the original training location used durng Tnals 1-40 Subjects were tested in this manner for 13 tnals (two trials/day) following which a second free swim tnal (see above descnption) was interposed on Tnal 54

In the final stage of testıng, anımals were traned for 7 tnals (two trals/day) in a cued version of the Morris task Dunng these trals (55-61), animals were tested exactly as described above with the exception that a visible black platform (see above description) was placed for each anımal in one of the two remaining quadrants not used during earlier phases of testıng The location of the platform across these cued tnals remaned constant for individual anımals

Two weeks following behavioral testıng, subjects were sacnficed by decapitatıon, and necropsy data were obtained by grossly inspectıng the pitutary gland of each subject for evidence of tumors

\section{Results}

Over the course of the first 31 training tnals in the place version of the Morris task, the mean escape latencies of all age groups decreased from $>90 \mathrm{~s}$ to $<10 \mathrm{~s}$ (see Figure 1). A two-way analysis of variance with repeated measures revealed a sıgnificant age effect, $F(2,20)=4.70, p<.02$, a significant trials effect, $F(30,900)=3190, p<.001$, as well as a significant Age $\times$ Tnals interaction, $F(60,900)=1.39, p<$ 05 . Subsequent separate analyses of the first half (Trials 116) and second half of training (Trials 17-31) indicated a significant age effect, $F(2,30)=581, p<.001$, and trials effect, $F(15,450)=2871, p<001$, for Trials $1-16$ with no significant interaction. Separate between-groups compansons revealed that aged subjects were imparred dunng the first half of training compared with either young, $F(1,20)=863, p<$ 01 , or middle-age subjects, $F(1,20)=662, p<02$ Inspection of the group data for Tnals $1-16$ also indicated that aged subjects generally exhibited longer escape latencies on the first trial of each day (1.e., Trials 5, 7, 9, and 13) compared with their performance on the second trial of that day (Trials 6,8 , 10, and 14; see Figure 1) No statistically significant differences were obtained for any variable durng the second half of training (Trials 17-31) Finally, between-groups compansons revealed no sıgnificant differences at any point in trainıng between young and middle-age anımals

On Trial 32, all subjects were permitted to swim in the maze for $90 \mathrm{~s}$ with the escape platform removed. During this free swim, all groups spent significantly more time in the quadrant of the apparatus that had previously contained the escape platform compared with other quadrants of the maze as revealed by one-way analyses of vanance (see Figure 2) young, $F(2,40)=56.87, p<001$; middle-age, $F(2,40)=$ $2861, p<.001$, senescent. $F(2,40$ ) $=3883, p<001$ (Note that in this and all subsequent analyses of quadrant time measures, the numerator degrees of freedom for the $F$ values have been reduced by one to reflect the fact that the total quadrant times necessarily add to $90 \mathrm{~s}$ This adjustment is not necessary for the annulus crossing measure since these crossings are independent of each other) Despite the slightly stronger spatial bias exhibited by young rats (see Figure 2), subjects of different ages appeared to spend equivalent amounts of time swimming in the training quadrant because no significant age differences were obtained Parallel results

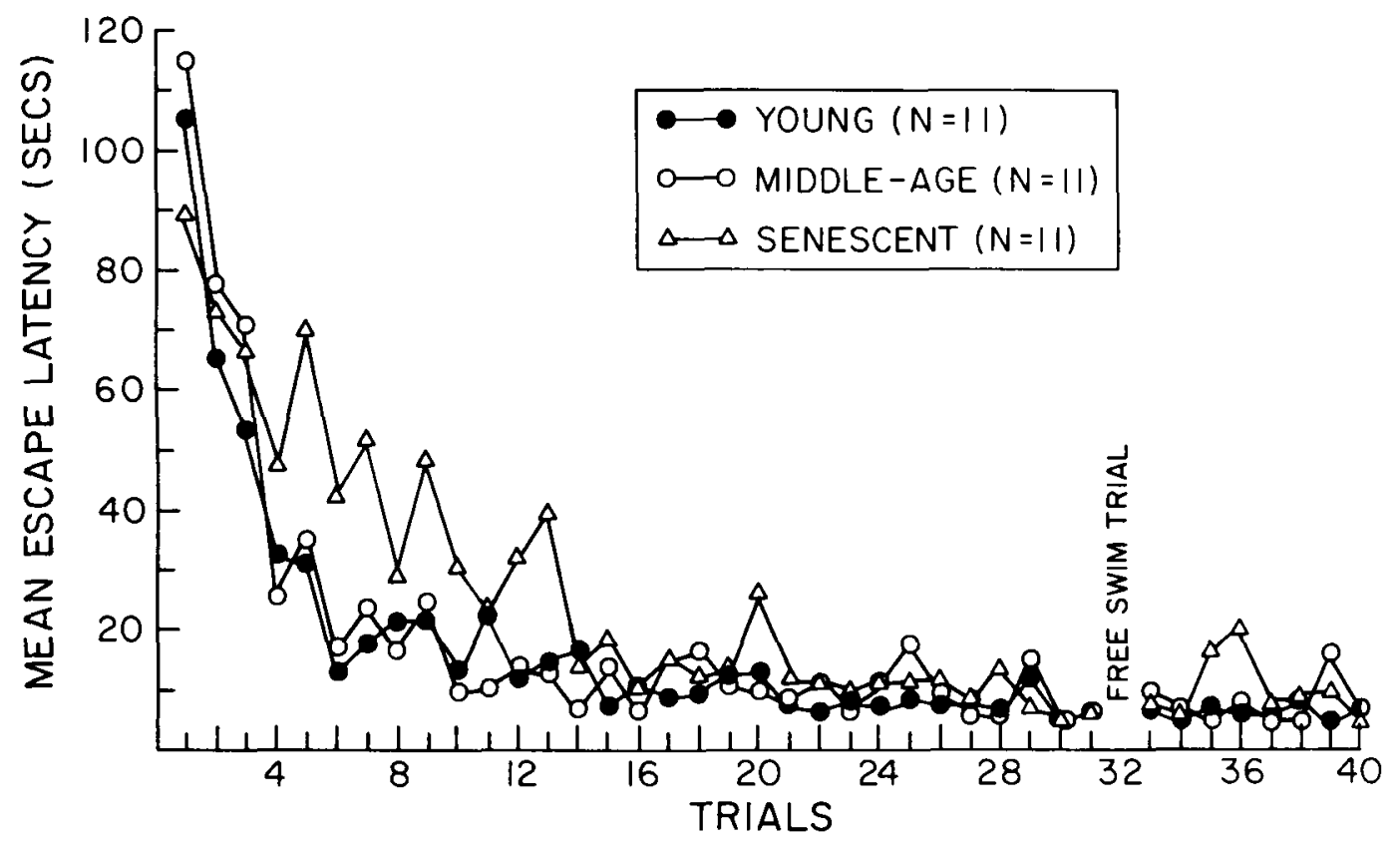

Figure I Mean escape latencies across Triais 1-40 for young. middle-age, and senescent rats durng place traınıng in Experıment 1 (On Tral 32, the anımals were given a 90-s free swim with no escape platform present .) 


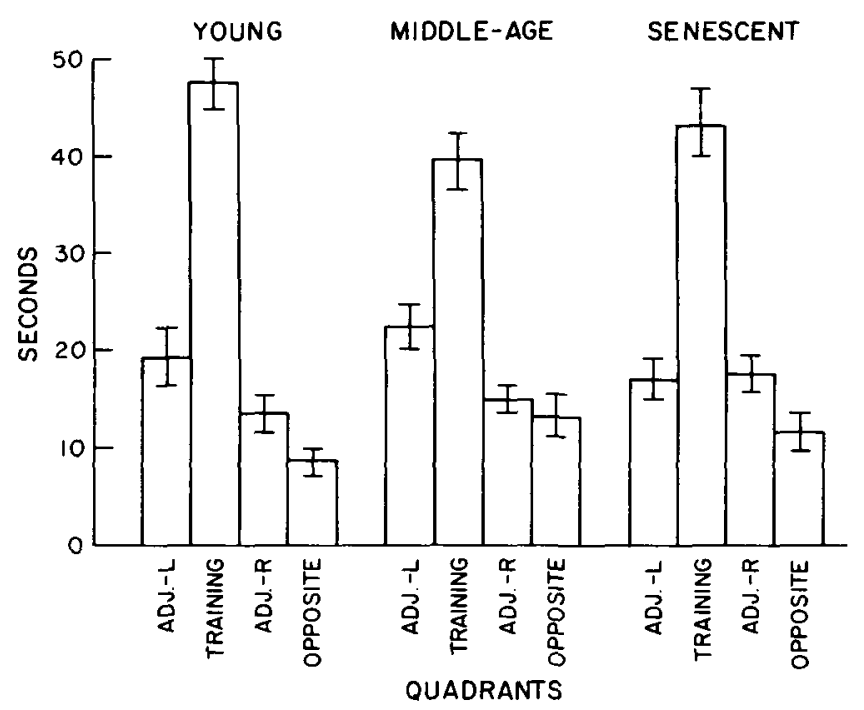

Higure 2 Mean number of seconds ( $\pm S E$ ) spent by young, middleage and senescent anımals in each quadrant of the water maze during the Trial 32 free swim in Expenment 1 (Quadrants are designated as follows Traming $=$ the quadrant of the maze that contaned the submerged escape platform dunng Tnals $1-31$, ADJ-L = the quadrant of the maze to the left of the training quadrant, $A D J-R=$ the quadrant of the maze to the night of the training quadrant. Opposite $=$ the quadrant of the maze directly opposite to the trauning quadrant )

to the quadrant times were observed in the annulus crossing data denved dunng this free swim trial (see Figure 3). Specifically, all groups crossed the training location of the escape platform significantly more often than other annulı of equal area in the center of the three remaining quadrants young, $F(3,40)=8552, p<.001$, middle-age, $F(3,40)=4359, p$ $<001$, and senescent, $F(3,40)=20.94, p<001$ Subsequent between-groups compansons falled to reveal a significant age difference in the number of training annulus crossings $\mathrm{Fl}_{\mathbf{l}}$ nally, both the quadrant measure and annulus crossings re-

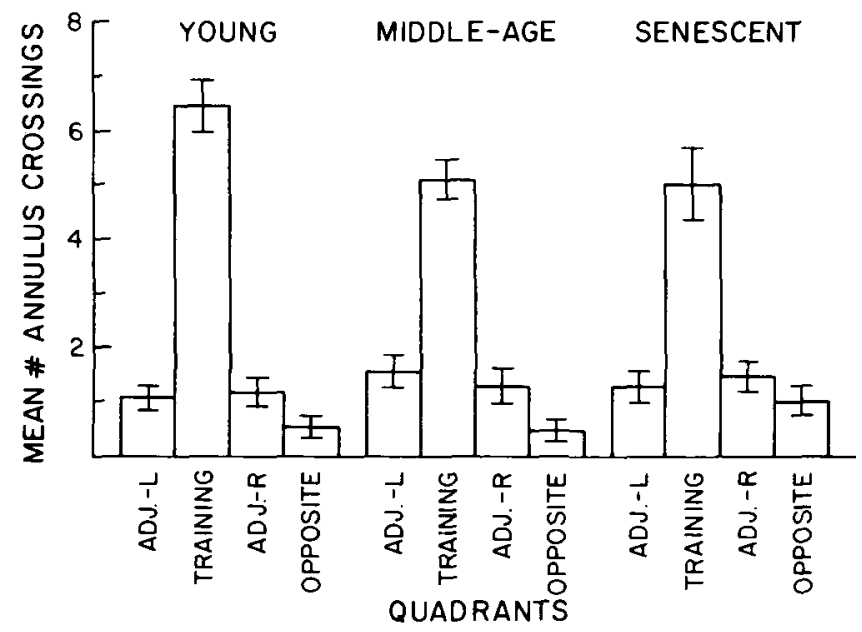

Figure 3 Mean number of annulus crossings $\pm S E$ for young. middle-age, and senescent rats dunng the Trial 32 frec swim in Experiment I (Quadrants aro designated as in Figure 2) vealed a similar profile of spatial behavior in all age groups: animals showed the greatest bias for the training quadrant and annulus location, the least preference for the quadrant and annulus opposite to the trainıng location, and an intermediate bias divided among the two quadrants adjacent to the trainıng quadrant.

During Trials $33-40$, subjects were tested in the place version of the task with the escape platform located in the same quadrant of the maze as dunng Tnals 1-31 (see Figure 1). Statıstical analysis of these data revealed no significant effect of age or tnals on performance indicatıng that the free swim tnal did not disrupt escape behavior in any group

For Trials 41-53 the hidden escape platform was moved to the center of the quadrant opposite to the onginal training location. Dunng this transfer training procedure, the mean escape latencies of all groups rapidly decreased from $>60 \mathrm{~s}$ on Trial 41 to comparable asymptotic levels of performance (see Figure 4) Statistical analysis verified the presence of a significant trals effect dunng transfer trainıng, $F(12,360)=$ $31.08, p<.001$. Despite the somewhat longer escape latencies of aged subjects on the second and third tnals of transfer traınıng, statıstical analysis revealed no stgnificant age effect during this phase of testıng. A comparable acquisition of spatial information across age groups was also indicated by the quadrant time and annulus crossing measures denved dunng the Tnal 54 free swim (data not shown). Specifically, all groups showed a significant spatial bias for the quadrant of the maze which had contained the escape platform dunng Trials 41-53. young, $F(2,40)=16.42, p<.001$, middle-age, $F(2,40)=902, p<.001$; senescent, $F(2,40)=2017, p<$ .001 . Parallel results were obtained in the annulus crossing measure such that all age groups showed a significant bias for the training location of the platform young, $F(3,40)=214$, $p<001$, middle-age, $F(3,40)=1710, p<001$, senescent, $F(3,40)=2368, p<001$ No statıstically signıficant differences, however, were observed between age groups as assessed by either the quadrant time or annulus crossing measure

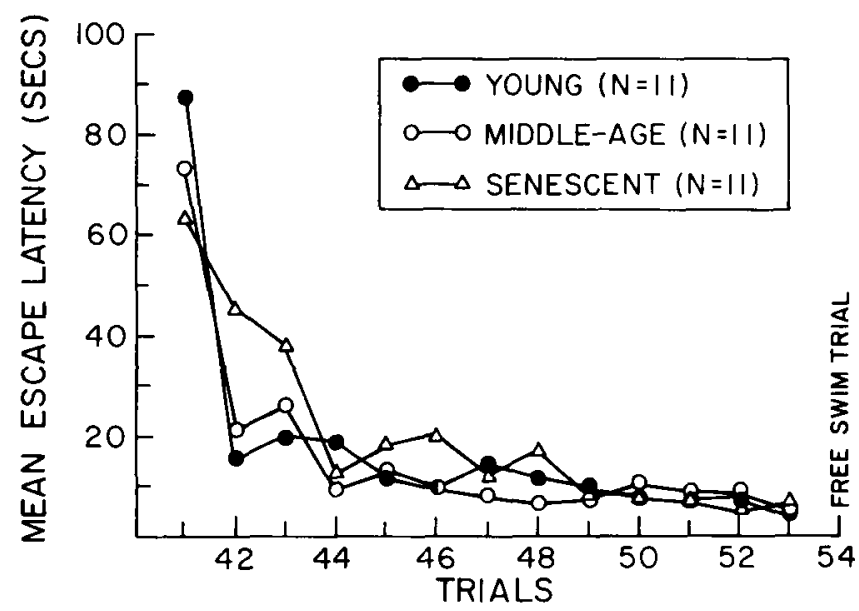

Figure 4 Mean escape latencies for young, middle-age, and senescent subjects during transfer trainıng (Trals 4l-53) in Experıment 1 (On Trial 54, the anımals were given an $90-\mathrm{s}$ frec swim with no escapc platform present ) 
For the final phase of testıng in Experıment I, subjects were tested across Tnals 55-61 in a cued version of the Morns task with a visible escape platform fixed in the center of a quadrant of the maze that, for individual anımals, was not used during pnor training The mean escape latencies of all groups during these trials decreased to equivalent asymptotic levels of $<5 \mathrm{~s}$ (see Figure 5) This observation was reflected in statistical analysıs that revealed a significant tnals effect, $F(6,174)=$ $2671, p<001$ This analysis did not, however, reveal a significant age effect

Finally, necropsy data obtained 2 weeks following behavloral testing revealed that 2 aged rats had large pitutary tumors which involved the entire gland. Durng behavioral testıng, however, escape latencies, quadrant times, and annulus crossings for these 2 subjects fell well within the range of values exhibited by other senescent rats.

\section{Discussion}

The results of the present experiment demonstrate that aged subjects exhibit initial deficits in the acquisition of water maze performance. In addition, the specific pattern of senescent escape performance early in training provides evidence that aged anımals are more profoundly imparred on the first trial of each day relative to their performance on the second trial of the same day This finding suggests that one important determinant of the observed imparment in the Morris task may be due to an age-related deficit in the retention of information important for task performance across days. This interpretation is consistent with other findings, which suggest that one prominent feature of senescent memory decline is an increase in the rate of forgetting of newly acquired information among aged subjects (Zornetzer, Thompson, \& Rogers, 1982) The present results further demonstrate that with contınued training, senescent rats acheve asymptotic levels of performance equivalent to young and middle-age subjects This general pattern of results is consistent with a number of previous investigations that have reported significant senescence-related initial deficits in 8-arm radial maze performance

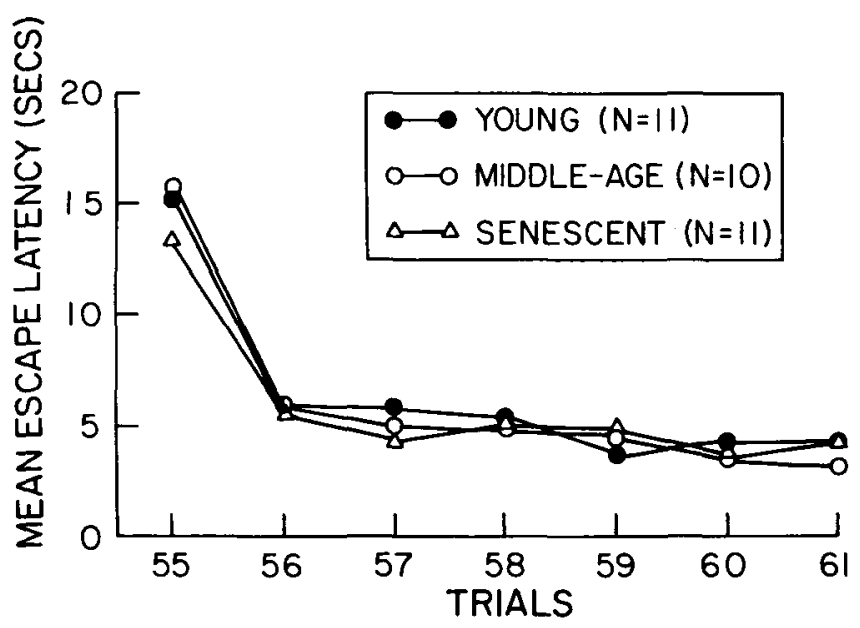

Figure 5 Mean escape latencies for young. middle-age, and senescent rats during cue training (Trials 55-61) in Experiment 1
(Barnes et al , 1980; Gallagher et al., 1985) Furthermore, the amelioration of ongunal acquisition deficits with continued trainıng is also a consistent finding across the studies cited. In contrast, other investıgations have demonstrated that aged animals exhibit persistent imparments in spatial behavior across a vanety of training procedures (Barnes, 1979, Davis et al , 1983; de Toledo-Morrell et al , 1983, de Toledo-Morrell et al , 1984; Gage et al , 1984. Ingram et al , 1981, Wallace et al., 1980). Because all age groups in the present experıment eventually reached equivalent asymptotic levels of performance, however, these results are important in as much as they suggest that aged rats have sufficient motonc capacity to perform well in the task Based on these findings, then, the hypothesis that deficits early in training in the Morns task result from generalızed motor detenoration in aged anımals would seem less tenable

The interpretation that learning in the Morris maze is primarily supponted by the presence of spatial information is consistent with the data obtained durng the free swim on Tnal 32. Durng this trial, all age groups showed as an equivalent and significant spatial bias for the previous location of the escape platform as well as for that quadrant of the maze that had contained the platform Since, as these data demonstrate, learning in the water maze is accompanied by a significant acquisition of spatial information, it appears reasonable to suggest that age-related imparments early in training in this task could reflect a specific deficit in the acquisition and/or retention of spatial information The notion that the senescent deficits observed in the present expenment specifically reflect impared spatial information processing is also consistent with results obtained during latter phases of training. Specifically, durıng transfer traınıng trals, all age groups showed similar acquisition of a novel platform location within the onginal testıng environment The equivalence of learning across age categones in this phase of testing is reflected by the lack of significant differences in escape latency across Trals $41-53$, as well as similar annulus crossing and quadrant tıme measures obtained dunng the second free swim on Tral 54 In conjunction, these findings provide evidence that given extensive exposure to the testıng environment, aged rats acquire sufficient spatial information to support levels of learning in the Morris task comparable to young control subjects.

Although the preceding hypotheses appear tenable on the basis of the findings obtained, the results discussed thus far provide no direct evidence as to the possible contribution of other nonspecific factors to senescent deficits seen early in training in the water maze The final phase of testing during Experiment 1 therefore used a cued version of the Morns task to assess whether sensory or motivational alterations in aged subjects might contribute to performance deficits among these anımals. Data obtained during Trials 55-61 demonstrate that age does not differentially affect performance in swimmıng to a novel, but visible escape location Therefore, to the degree that behavior in the cued version of the Morris task is guided by the presence of the visible goal, these data suggest that aged rats have sufficient sensory capacity to locate a visible escape platform and that they are motivated to perform in the task

Although these findings are consistent with the interpretation that age-related deficits in the Morris task reflect a 
senescent decline in the abilsty to acquire or utilize spatial information, a plausible alternative is that aged subjects are impaired in learning other nonspatial task contingencies If, for example, aged rats require more tnals than young subjects to learn that a means of escape is provided in the maze, acquisition deficits among senescent anımals might reflect impaired retention for this information rather than impared spatıal information processing, per se. Furthermore, because aged rats are known to exhıbit increased neophobıa in other behavioral testıng procedures (Brennan, Blızard, \& Quartermain, 1982, Collier \& Sladek, 1984, Goodrick, 1967), it may be that a persistence of neophobic reactions among aged anımals during water maze training interferes with the acquisition or retention of information that is critical for normal task performance. Note that neither of these possibilities is well addressed by the inclusion of cue training in Expenment 1 since, by this point in trainıng, senescent subjects had been extensively tested and were found to have acquired sufficient spatial information to support normal performance in the task Expenment 2, therefore, investigated water maze acqulsition in naive young and old rats in the cued version of the task that does not require the utilization of spatial information Intial cue training should thereby provide evidence as to whether nonspatial task vanables contribute importantly to performance differences between young and aged rats. Two weeks following cue training in Expenment 2, young and senescent subjects were tested in the place version of the task exactly as described in Experiment 1 Thus, by providing extensive pnor experience in the maze, this design was intended to minimize the neophobic response of aged animals dunng subsequent place trainıng.

\section{Experiment 2}

\section{Method}

In Expenment 2, naive groups of young ( 4 months, $n=13$ ) and aged (23-25 months, $n=11$ ) male Long-Fvans hooded rats (Charles River Laboratones) were initially trained in the cued version of the Morns task as described above For this expenment. the testung environment and apparatus were the same as 1 n Expenment ! Subjects were trained over Trials 1-13,2 trials per day, with the visible black platform always located in the center of one quadrant for each individual animal The platform location among anımals in each group, however, was counterbalanced As in Experiment 1, a 60-s intertnal interval was imposed, dunng which the animal remaned on the escape platform A 120-s cutoff was used on all trals Immediately following the last cue trainıng trial, anımals were given a 90-s free swim as described above

Following traınıng as outlıned, anımals were not tested in the maze for 2 weeks Subsequently, all subjects in Expenment 2 were trained in the place version of the Morris task exactly as described in Expenment I for 7 Inals Durng this phase of testıng, the submerged platform was fixed for each subject in the center of the quadrant of the maze opposite to the cued platform location used earlier in trainıng Immediately following Tnal 7, subjects were given a 90-s free swim as described above

Finally, 2 weeks following behavioral tesung, all subjects were sacrificed by decapitation, and necropsy data were obtained by inspecting the piturtary gland of cach subject for evidence of tumors

\section{Results}

Durng cue trainıng Trials 1-13, the mean escape latencies of young animals and senescent subjects decreased from

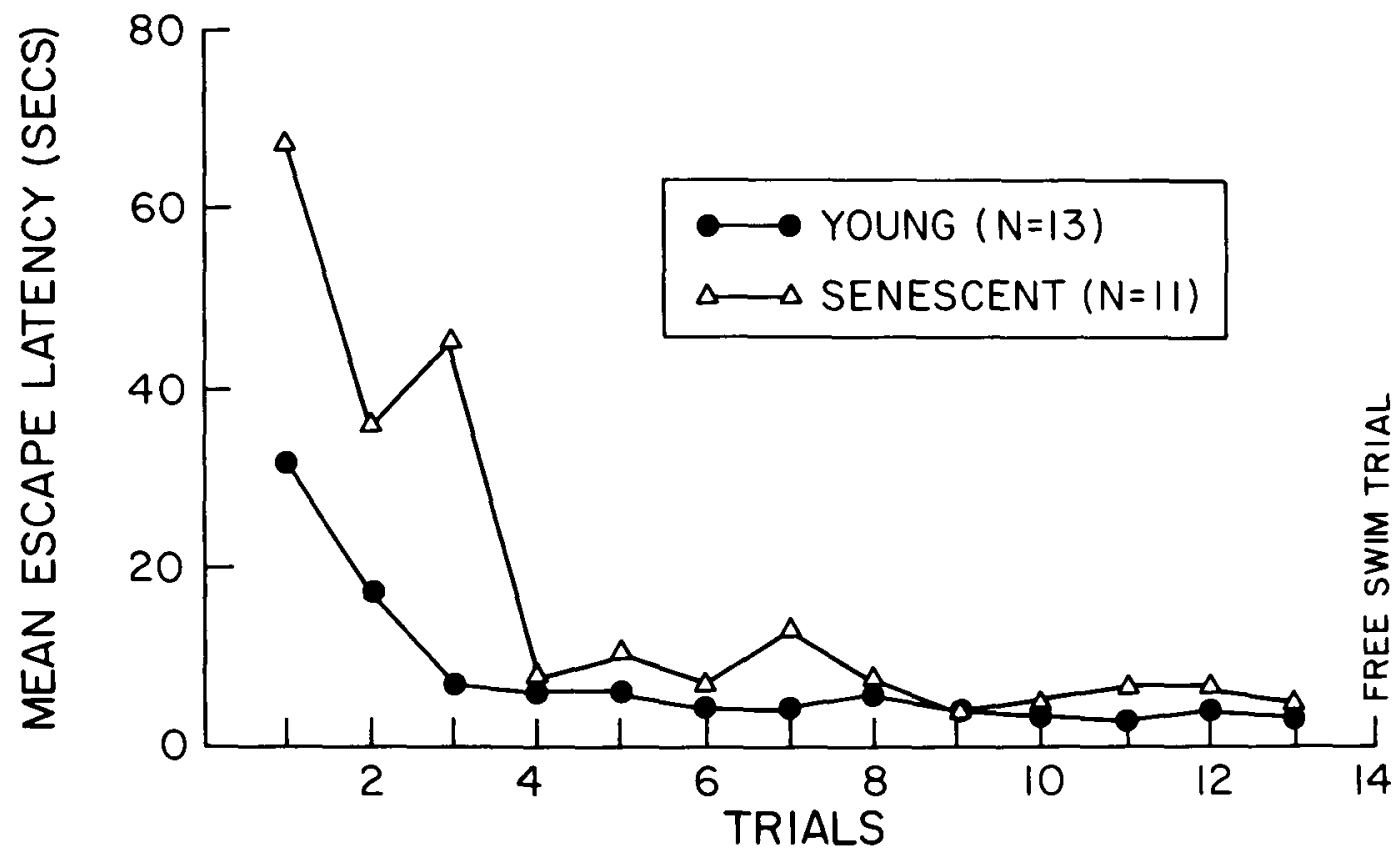

Figure 6 Mean escape latencies across Tnals 1-13 for young and senescent rats durng cue trainıng in Experiment 2 (On Tnal 14, subjects were given a 90-s free swim with no escape platform present) 
greater than $35 \mathrm{~s}$ and $65 \mathrm{~s}$, respectively, to below $8 \mathrm{~s}$ (see Figure 6) A two-way analysis of variance with repeated measures revealed a significant trials effect, $F(12,264)=$ $1637, p<001$, a significant age effect, $F(1,22)=2303, p<$ 001 , as well as a significant Tnals $\times$ Age interaction, $F(12$, 264) $=3.81, p<001$ Individual tral compansons, however, revealed that by the end of cue training, both groups achieved equivalent asymptotic levels of performance Immediately following Tral 13, subjects were given a 90-s free swim Aged subjects showed no spatıal bias during this tral as assessed by etther the quadrant or annulus crossings measures (see Figures 7 and 8) In contrast, quadrant time measures derived during the Trnal 14 free swim showed that young anımals spent the greatest amount of tume swimming in that quadrant of the maze which had contained the cued escape platform (see Figure 7) Statıstıcal analysıs revealed this effect to be significant $F(2,48)=508, p<.01$ For young anımals, the pattern of time spent in each quadrant was also observed to be similar to results obtained in Experiment 1, with the greatest amount of time spent in the training quadrant, the least amount of tıme spent swimming in the opposite quadrant, and the remaining tıme approxımately equally distributed among the half of the maze adjacent to the training quadrant Among young subjects, the pattern of annulus crossings also paralleled these quadrant measure results (see Figure 8) There were, however, no statistically significant differences in the number of tımes young anımals crossed the four annulı locations $A$

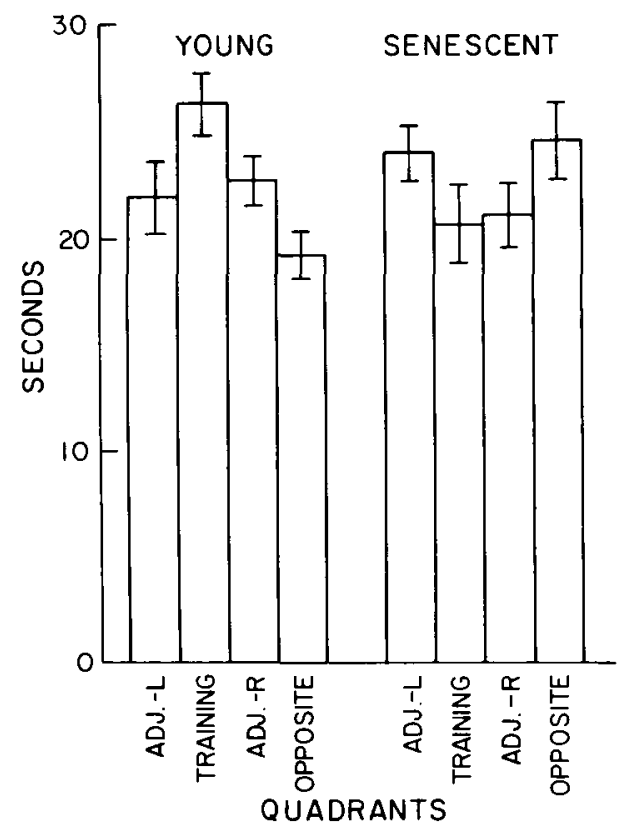

Figtre 7 Mean number of seconds $\pm S E$ spent by young and senescent rats in each quadrant of the maze during the Trial 14 free swim in Experiment 2 (Quadrants are designated as follows Training $=$ the quadrant of the maze that contained the cued escape platform dunng Tnals $1-13, A D J-L=$ the quadrant of the maze to the left of the traming quadrant. $A D J-R=$ the quadrant of the maze to the nght of the Iraining quadrant. Opposite = the quadrant of the maze directly opposite to the trainıng quadrant )

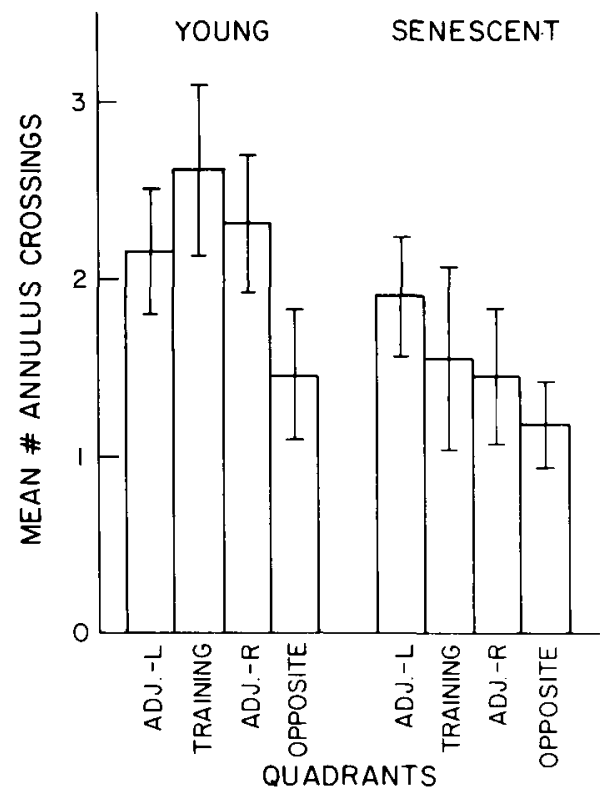

Figure 8 Mean number of annulus crossings \pm SE for young and senescent rats during the Trial 14 free swim in Experiment 2 (Quadrants are designated as in Figure 7 )

finer grained analysis of these data was performed by measuring each anımal's latency to its first crossing of the tranıng location of the platform These data yielded a median latency of $70 \mathrm{~s}$ for young animals and a median latency of $407 \mathrm{~s}$ for senescent subjects. Statistical analysis by a Mann-Whitney $U$ test (two-talled) revealed these results to be significant, $p<$ $.05, U=32$

Two weeks following the end of cue training, subjects were tested in the place version of the Morns task, with the hidden platform located in the quadrant of the maze opposite to the cued platform location used earlier in testıng Durıng Trials $1-7$, the mean escape latencies of both groups decreased as revealed in a significant trals effect for these data (see Figure 9), $F(6,132), p<001$ A significant age effect was also obtaned, $F(1,22)=4.23, p<05$, which reflected the longer escape latencies of aged subjects throughout place training

Immediately following the last training trial, subjects were provided a second free swim Quadrant times measured during this tral revealed that young subjects spent the greatest proportion of time swimming in the quadrant of the maze that had contained the submerged platform (see Figure 10) This effect was statıstically significant, $F(2,48)=1765, p<$ $.001 \mathrm{~A}$ similar bias among young rats was also observed for the training location of the platform as assessed in the annulus crossing measure (see Figure 11). Again, this effect was signif1cant, $F(3,48)=13.91, p<001$ In contrast, Trial 8 freeswim data revealed no significant spatial bias among aged rats in either quadrant tıme or annulus crossings measures

Finally, 2 weeks following the completion of behavioral testıng, subjects from Experiment 2 were sacnficed by decapitation. Necropsy data revealed no evidence of pituitary tumors in any subjects used in this investigation 


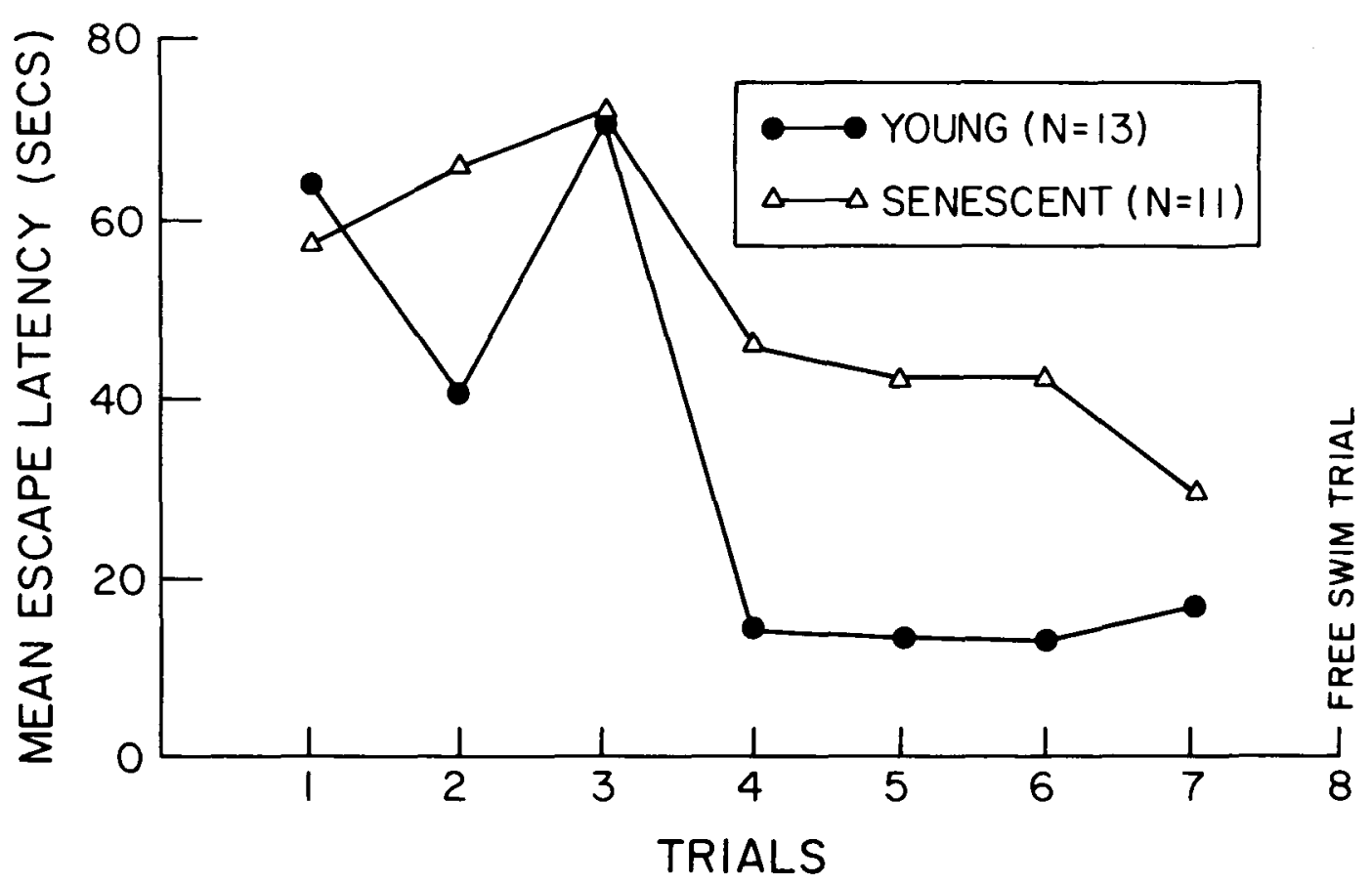

Figure 9 Mean escape latencies across Trals 1-7 for young and senescent rats during place training in Experıment 2 (On Tral 8, the anımals were given a 90-s free swım with no escape platform present)

\section{Discussion}

The results of Expenment 2 demonstrate that naive aged subjects are impared dunng early phases of cue training in the Morris water maze Importantly, however, the results obtained indicate that age-related deficits in the cued version of the task are primanly confined to the first three trals of training (see Figure 6) Therefore, because the impaired performance of senescent subjects in Expenment 1 became apparent only after the first three trals (see Figure 1), it would appear unlikely that the factors contributing to senescent deficits in cued performance are responsible for the impairments observed dunng place trainıng Furthermore, the results of cue training in Expenment 2 indicate that nonspatial learning imparments in senescent subjects do not prevent rapid and substantial acquisition in the task as reflected in the good performance of aged anımals after Trial 3. Indeed, the impaired performance of older rats dunng the first several tnals of cue training in the present expenment may, in part, reflect impaired spatial information processing among senescent subjects, since a spatial strategy could be used to solve the cued version of the task used here Additional data relevant to this proposal are discussed below. In any case, the confluence of these data provide strong support for the proposal that sensory and motor dysfunctions in aged rats are not sufficient to account for the senescent deficits observed during place training Direct evidence that aged animals do have a specific deficit in processing spatial information is also provided by the results of Experiment 2 Data obtained during the first free swim on Tral 14 clearly demonstrate that during cue trainıng in the Morris maze, young subjects acquire a significant amount of spatial information, whereas aged rats exhibit no evidence of similar learning. Moreover, this age difference occurs despite senescent subjects having had greater exposure to the testıng environment by virtue of their initially longer escape latencies These results are consistent with other data demonstratıng that compared with young subjects, aged anımals preferentially use nonspatial stategies to solve tasks when such alternatıve strategies are avallable (Barnes et al, 1980)

In the final phase of testıng in Expenment 2, aged subjects exhibited impaired escape performance during place training in the Morns task. Because both age groups appeared to benefit substantially and equally from their pnor expenence in the maze (1.e., compare Trial 1 escape latencies in Figures 1 and 9), it does not appear likely that a persistence of neophobia in senescent subjects contributes importantly to age-related deficits during subsequent place tranning Furthermore, age-related acquisition deficits in place training in Experiment 2 are probably not due to behavioral inflexibility among senescent subjects ( $1 \mathrm{e}$, a persistence of swimming to the former cued platform location), since the results of transfer training in Experiment 1 demonstrate that aged rats are not impaired in learning a novel spatial location within the onginal testing environment Direct evidence that the deficits observed among senescent rats pnmanly reflect imparred spatial information processing is provided by the free swim data obtained following place training. These results demonstrate that deficits early in place training in the Morris task are accompanied by a profound lack of acquisition of spatial 


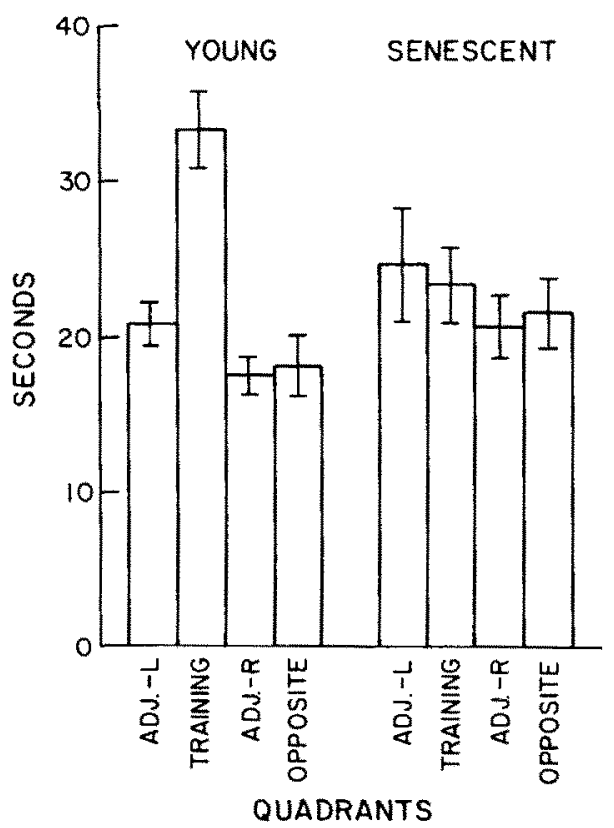

IIgule (f) Mean number of seconds $\pm S E$ spent by young and senescent rats in each quadrant of the maze during the Trial 8 free swim in Experıment 2 (Quadrants are designated as follows Traınıng = the quadrant of the maze that contained the submerged escape platform during Trials $1-7$. ADJ-L $=$ the quadrant of the maze to the left of the traınıng quadrant, ADJ-R = the quadrant of the maze to the nght of the training quadrant, Opposite = the quadrant of the maze directly opposite to the trainıng quadrant)

information among aged subjects Indeed, given the results described, it is not unreasonable to suppose that the acquisiton of spatial information among young subjects during pnor cue trainıng may have served to facilitate later place learnıng in these subjects

\section{General Discussion}

The experiments described here demonstrate that aged rats exhibit marked impairments during place training in the Morns water maze These findings are in general agreement with other recently reported data (Gage et al., 1984) and provide substantial additional evidence supporting the interpretation that aged rats have a specific impairment in their ability to process spatial information In addition, this research suggests that the Morns water maze may be a particularly sensitive procedure with which to test the nature of cognitive dysfunctions in senescence Given the substantial literature delıneatıng neuroanatomical sites and neurochemical mechanısms involved in mediatıng spatial learning, the present experiments may also facilitate efforts to identify candidate neural substrates of age-related spatial learnıng imparments Current expenments are, therefore, underway in our laboratory to investigate age-related neurochemical dynamics and their relation to deficits in processing spatial information

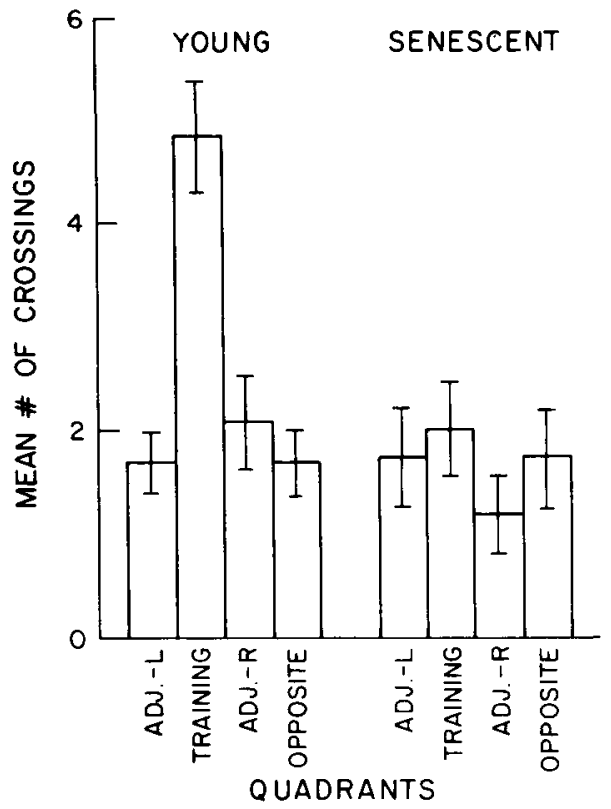

Figure /] Mean number of annulus crossings $\pm S E$ for young and senescent rats during the Trial 8 free swim in Experiment 2 (Quadrants are designated as in Figure 10 )

\section{References}

Barnes, C A (1979) Memory deficits associated with senescence A neurophysiological and behavioral study in the rat Journal of Comparative and Phvsological Psychology, 93, 74-104

Barnes, C A, Nadel, L, \& Honig. W K (1980) Spatial memory deficits in senescent rats Canadian Journal of Pichologin, 34, 2939

Botwinick, J (1978) Aging and Behavior (2nd ed) New York Springer

Bremnan, M J , Blızard, D A . \& Quartermain, D (1982) Amelioration of age-related deficits in exploning behavior by preexposure to the test environment Behavoral and Neural Bologl, 34, 5562

Collier, T J, \& Sladek. J R (1984) Increased neophobia Behavioral identification of a subpopulation of memory-impaired norepinephrine-deficient aged F344 rats Society for Neuroscience Ahstructs, 10,772

Davis, H P, Indowu. A, \& Gibson. G E (1983) Improvement of 8-arm maze performance in aged Fischer 344 rats with 3.4.-diaminopyridıne Experimental Aging Reweare h, 9, 211-214

de Toledo-Morrell, L . Morell. F , \& Fleming. S (1984) Age-dependent deficits in spatial memory are related to impaured hippocampal kinding Behwvioral Neurosctence, 98, 902-907

de Toledo-Morrell. L. Morrell, F, Fleming, S, \& Cohen, M M (1984) Pentoxifylline reverses age-related deficits in spatial memory Behavioral and Nenral Bologi, 42, 1-8

Gage, F H , Dunnett, S S, \& Bjorklund, A (1984) Spattal learnıng and motor deficits in aged rats Neturobiologl of 4ging, 5, 43-48

Gallagher, M, Bostock, E. \& King, R (1985) Effects of oplate antagonists on spatial memory in young and aged rats Behavioral and Neural Blologi, 44, 374-385

Goodrick, C L (1967) Exploration of nondeprived male SpragueDawley rats as a function of age Psichological Reports, 20. 159163 
Ingram, D K, London, E D , \& Goodnck, C L (1981) Age and neurochemical correlates of radial maze performance in rats Neurobuologi of Aging, 2, 41-47

Kubanıs, P , \& Zornetzer, S F (1981) Age-related behavioral and neurological changes A review with emphasis on memory Behavworal and Neural Biologi. 31, 115-172

Morns, R G M (1981) Spatial localization does not require the presence of local cues Learning and Motivation, 12, 239-260

Morns, R G M. Garrud, P. Rawlıns. J N P , \& O'Keefe, J (1982) Place navigation is impaired in rats with hippocampal lesions Nature, 297, 681-683

Morris. R G M . Garrud, P, \& Woodhouse, I Q (1980) Fornix lesıons disrupt location learning by the rat Behavioral Brain Reseurch, 2, 266

O'Keefe. J, \& Nadel, 1. (1978) The hippocampus as a cognitlve map Oxford Clarendon Press
Schenk, F , \& Morris, R G M (1985) Dissociation between components of spatial memory in rats after recovery from the effects of retrohippocampal lesions Experimental Brain Research, 58, 1128

Sutherland, R J , \& Dyck. R H (1983) Hippocampal and neocortical contributions to spatial learning and memory Society for Neuroscience Abstracts, 9, 638

Wallace, J E, Krauter, E E , \& Campbell, B A (1980) Anımal models of declining memory in the aged Short-term and spatial memory in aged rats Journal of Gerontologi. 35, 355-363

Zornetzer, S F. Thompson, R , \& Rogers, J (1982) Rapud forgettung in aged rats Behavtoral and Neurat Blologl, 36, 49-60

Received July 2, 1985

Revision received January 21, 1986

\section{Correction to Thomas and Gash (1986)}

In the article "Differential Effects of Postenor Septal Lesions on Dispositıonal and Representational Memory" by Garth J Thomas and Don M Gash (Behavioral Neuroscience, 1986, Vol. 100, No 5, pp 712-719), a phrase was erroneously deleted from the text In the seventh paragraph on p. 713, the second sentence should read as follows Early in training individual differences were great, but by the end of adaptation training, individual differences were quite small and all rats responded at close to asymptotic speeds. 